Review

\title{
Analysis of Benzo[a]Pyrene Contamination from an Long- Term Contaminated Soil
}

\author{
${ }^{1}$ Svetlana Sushkova, ${ }^{1}$ Tatiana Minkina, ${ }^{2}$ Abdulmalik Batukaev, ${ }^{1}$ Irina Turina, \\ ${ }^{1}$ Saglara Mandzhieva, ${ }^{3}$ Galina Vasilyeva, ${ }^{4,5}$ Rıdvan Kızılkaya, ${ }^{1}$ Inna Zamulina and ${ }^{6}$ Izzet Akca \\ ${ }^{1}$ Southern Federal University, Rostov-on-Don, Russian Federation \\ ${ }^{2}$ Chechen State University, Grozny, Russian Federation \\ ${ }^{3}$ Institute of Physicochemistry and Biological Problems of Soil Sciences Russian Academy of Sciences, Pushchino, \\ Moscow Region, Russian Federation \\ ${ }^{4}$ Department of Soil Science and Plant Nutrition, Faculty of Agriculture, Ondokuz Mayls University, Samsun, Turkey \\ ${ }^{5}$ Agrobigen R\&D Ltd.Co. Samsun Technopark, Ondokuz Mayls University, Samsun, Turkey \\ ${ }^{6}$ Department of Plant Protection, Ondokuz Mayls University, Faculty of Agriculture, Samsun, Turkey
}

Article history

Received: 22-09-2015

Revised: 02-11-2015

Accepted: 06-11-2015

Corresponding Author:

Svetlana Sushkova

Southern Federal University,

Rostov-on-Don, Russian

Federation

Email: snsushkova@sfedu.ru

\begin{abstract}
Analysis of benzo[a]pyrene contamination from an aged contaminated chernozemic, meadow-chernozemic and alluvial soils under the effect of aerotechnogenic emissions from the Novocherkassk regional power plant have been revealed on the basis of annual monitoring studies from 2008 to 2012. A new ecologically clean highly-effective expressmethod of subcritical water extraction has been developed for determination of benzo[a]pyrene from soils of the emissions zone. It has been found that the $5-\mathrm{km}$ zone to the northwest and west from the power station, which coincides with the predominant wind directions, is most subjected to contamination by benzo[a]pyrene, with the maximum accumulation at a distance of about $1.6 \mathrm{~km}$ from the emissions source. The vertical distribution coefficients of benzo[a]pyrene between the $0-5 \mathrm{~cm}$ and 5-20 cm layers closely correlate with the contents of physical clay, clay, organic matter and cation exchange capacity. It has been shown that the content of benzo[a]pyrene in the soil is an indicator of the technogenic pressure impact on the areas, for which the combustion products of hydrocarbon fuel are the major pollutants.
\end{abstract}

Keywords: Soil, Benzo[a]pyrene, Subcritical Water Extraction, Monitoring, Regional Power Plant

\section{Introduction}

Polycyclic Aromatic Hydrocarbons (PAHs) are a typical class of persistent organic compounds derived from natural sources such as forest fires or/and anthropogenic processes such as urban and industrial activities and are prevalent in the environment. Sixteen PAHs compounds have been recommended as priority pollutants by the United States Environmental Protection Agency (USEPA) because of their carcinogenicity, mutagenicity and toxicity (Anonymous, 2002; GOST 17.4.1.02.-83, 2004; Jian et al., 2004; Wenzl et al., 2006). These compounds are likely to accumulate in soils for many years because of their persistence and hydrophobicity. As a result, soils may be an important reservoir of PAHs (Oros et al., 2007).

Benzo[a]Pyrene (BaP) is most frequently considered as the main marker of soil contamination by PAHs, because this is the most prevalent PAH characterized by a very high persistence in environmental objects and elevated carcinogenicity and mutagenicity (Jian et al., 2004). BaP is a compound of hazard class I; it is included in the group of super toxic compounds and its content in all objects of the ecosystem is subject of mandatory control (Wenzl et al., 2006; Tobiszewski and Namiesnik, 2012). In Russia, the Maximum Permissible Concentration (MPC) of $\mathrm{BaP}$ is $0.02 \mathrm{mg} \mathrm{kg}^{-1}$ for all soils; in other countries, this value varies in the range of $0.1-2.7 \mathrm{mg} \mathrm{kg}^{-1}$.

The monitoring studies of environmental pollution with PAHs has been performed in many countries over tens of years. A number of works well with the study of the state of the areas subjected to technogenic contamination with PAHs (Callén et al., 2013; Pereira et al., 2013; Singh et al., 2013; Sushkova et al., 2015a; Witter et al., 2014; Li et al., 
2006; Yam and Leung, 2013; Zhu et al., 2014). The contamination is of technogenic origin in all the cases.

Active sources of environmental pollution with PAHs include enterprises of energy industries, especially great thermal stations (Anonymous, 2002; Sushkova et al., 2015b; Witter et al., 2014; Yam and Leung, 2013). The Thermal Power Plant in Novocherkassk (TPPN) is one of the greatest thermal power stations not only in Russia, but also in Europe. This is an enterprise of hazard class 1, which was set in operation in 1965-1971. At present, it includes eight working blocks and is the main source of electrical energy in Rostov oblast. Coal and natural gas are the major fuel types for the station. The height of the first chimneystack is $185 \mathrm{~m}$; the three other stacks are $250 \mathrm{~m}$ high.

Ecological monitoring performed since 2000 showed that the TPPN is the main pollution source of the atmospheric air not only in the city of Novocherkassk, but also in the entire Rostov oblast and makes the major contribution to the environmental pollution in this region. The aim of the current work was to study the main tendencies in the accumulation and distribution of $\mathrm{BaP}$ in soils of the affected zone of the TPPN.

The purpose of research is the analysis of $\mathrm{BaP}$ contamination from an aged contaminated soils using subcritical water extraction.

\section{Materials and Methods}

The main objects of study were soils in the affected zone of the TPPN. The satellite images of the TPPN and its affected zone, as well as the locations of monitoring plots, are given in Fig. 1. According to Russian Federation State Standard System (GOST 17.4.4.02-84, 1986) location of monitoring plots was carried out in view of the vertical structure, heterogeneity of soil cover, relief and climate areas, as well as the characteristics of the pollutants. Monitoring plots for soil samples analysis had the same place with the air sampling sites for the ecological certificate of the plant (plots 1, 2, 3, 5, 6, 7) (Fig. 1). The most attention was paid to the main wind direction from the contamination source to the northwest and west through the residential areas of Novocherkassk (zones 4, 5, 8, 9, 10) (Table 1).

The map was marked location of the source of pollution, monitoring plots. Trial plots are located in accordance with (GOST 17.4.3.01-83, 2004), which establishes requirements for sampling soil at the general and local pollution. Monitoring plots have been identified on the grid with non-uniform spacing of the typical elements of the relief on soils contaminated unevenly. The distance between monitoring plots have been identified taking into account the distance from the source of contamination and the prevailing wind direction.

The monitoring plots were located on virgin lands or fallow areas. Most of the area in the affected zone of the
TPPN is occupied by calcareous Ordinary Chernozem (Co); Meadow-Chernozemic Soil (MCS) (plot 3SW) and Alluvial Soil (AS) also occur in the Tuzlov River floodplain of the studied zone (Table 1).

The Co and MCS have thick organic matter horizons $(70-100 \mathrm{~cm})$, relatively high content of organic matter (2.4-2.9\%) and high Cation Exchange Capacity (CEC) $(31.2-47.6 \mathrm{cmol}(+) / \mathrm{kg})$, including a high content of exchangeable calcium $(76-90 \%$ of total exchangeable cations) and neutral or weakly alkaline reaction (pHwater 7.4-7.7) (GOST 26423-85, 1985). According to particle size distribution, they belong to heavy loamy and light clayey varieties developed on calcareous loesslike rocks. The climatic index of biological productivity (Bc) is 90-100 under natural conditions and 170-175 under optimum wetting conditions. The sufficient amount of heat and precipitation forms soils with high natural fertility and the enrichment with carbonates from the parent rocks favors the development of high buffering properties. The alluvial soil has light texture, thinner organic matter horizon $(40-60 \mathrm{~cm})$, lower organic matter content (lower than 1.8\%) and lower CEC (10.6 $\mathrm{cmol}(+) / \mathrm{kg})$ with a relatively high content of exchangeable calcium (Table 2).

Soil samples were taken annually from 2002 to 2012 and prepared for chemical analysis in accordance with the current requirements (Directive document 52.10.556-95, 2002; Certificate 27-08, 2008; GOST 17.4.3.01-83, 2004). Soil sampling has being taken yearly in the second half of June in the period of the active plant growth and development. The samples were taken by layers, from depths of 0 to 5 and 5 to $20 \mathrm{~cm}$. Soil samples were selected and prepared for the chemical analysis according to GOST 17.4.4.02-83 (GOST 17.4.1.02.-83, 2004) requirements. All samples were stored in refrigerator to preserve the $\mathrm{BaP}$ destruction. Storage and subsequent analysis of the soil samples was carried out according to international standards (ISO 13877-2005, 2005; Certificate 27-08, 2008).

The samples were used for the determination of soil texture by the Kachinskii method (Sokolov, 1975).

Solvents and reagents were HPLC grade and included ethanol ( $96 \%$, analytical grade), $n$-hexane (99\%, analytical grade), potassium hydrate $(98 \%$, analytical grade), acetonitrile (99.9\%, analytical grade), $\mathrm{NaOH}(97 \%$, analytical grade) and anhydrous $\mathrm{Na}_{2} \mathrm{SO}_{4}$ (purchased from Aquatest, Rostov on Don, Russia). A BaP standard solution in acetonitrile (Sigma-Aldrich, Germany) was used to prepare standards for HPLC analysis.

$\mathrm{BaP}$ extraction from soils was carried out by a subcritical water extraction method (Sushkova et al., 2015a; 2014; 2013). The sequence of operations when carrying out the analysis is schematically shown in Fig. 2. 


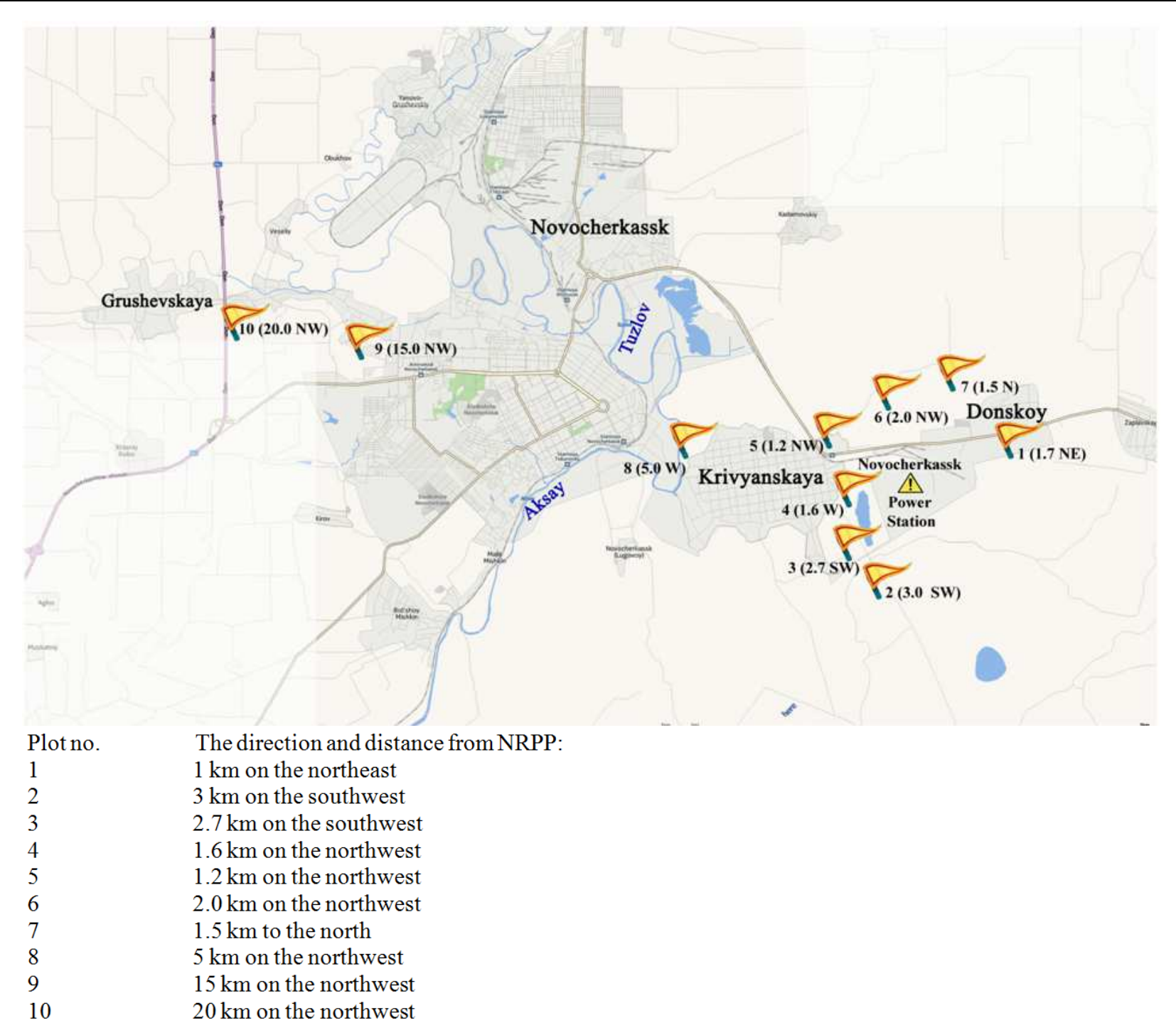

Fig. 1. Schematic map of monitoring plots in the zone affected by the NRPP

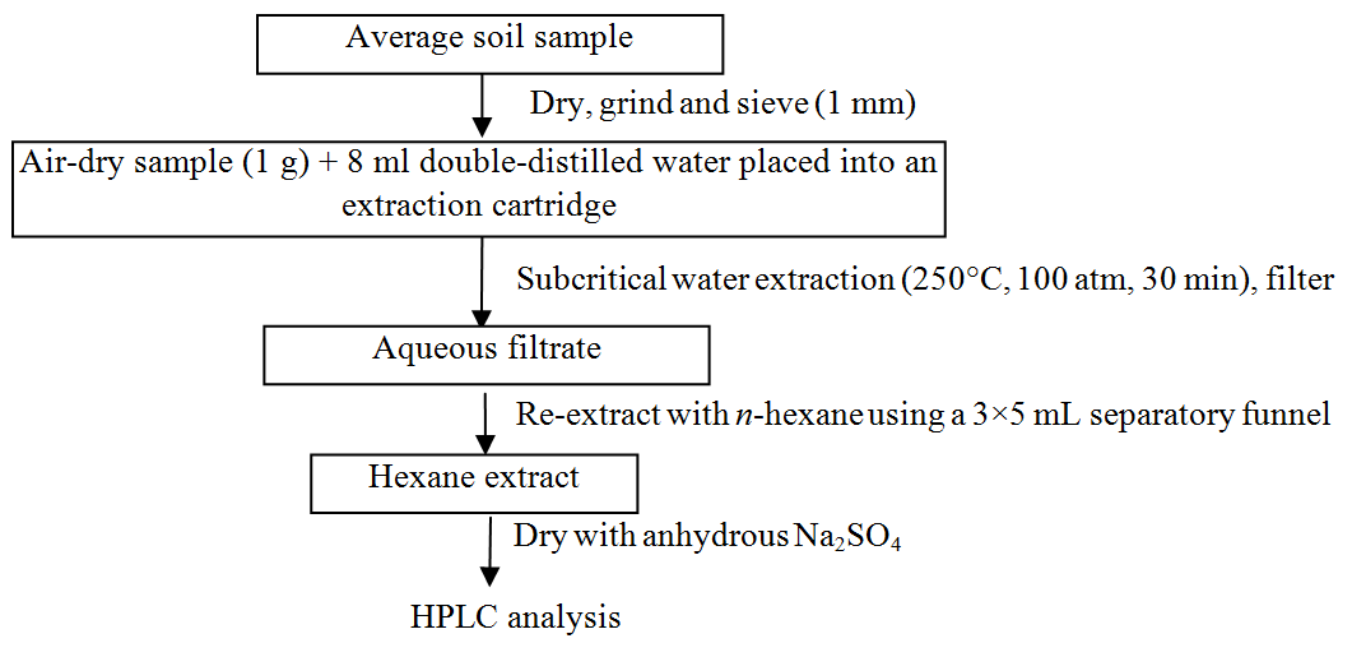

Fig. 2. Scheme of BaP analysis in soil material using subcritical water extraction and HPLC analyses of the extract 
Table 1. Numbers of monitoring plots and their code including distance $(\mathrm{km})$ and the direction from TPPN and also soil type on a plot

\begin{tabular}{|c|c|c|c|c|c|}
\hline \multirow[b]{2}{*}{ № } & \multicolumn{3}{|c|}{ Group I } & \multicolumn{2}{|c|}{ Group II } \\
\hline & Code & Soil type & № & Code & Soil type \\
\hline 5 & $1.2 \mathrm{nw}$ & $\mathrm{Co}$ & 1 & lne & $\mathrm{Co}$ \\
\hline 4 & $1.6 \mathrm{nw}$ & Co & 7 & $1.5 \mathrm{n}$ & Co \\
\hline 8 & $5 \mathrm{nw}$ & MCS & 6 & $2 n$ & MCS \\
\hline 9 & $15 \mathrm{nw}$ & Co & 3 & $2.7 \mathrm{sw}$ & MCS \\
\hline 10 & $20 \mathrm{nw}$ & $\mathrm{Co}$ & 2 & $3 \mathrm{sw}$ & AS \\
\hline
\end{tabular}

Table 2. Properties of TPPN emissions zone soils (an average for 2008-2012)

\begin{tabular}{llllllll}
\hline Number of monitoring plot & Soil type & Physical clay, $(\%)$ & Clay, $(\mathbf{\%})$ & $\mathrm{C}_{\text {org }},(\%)$ & $\mathrm{pH}$ & $\mathrm{CaCO}_{3},(\%)$ & $\mathrm{CEC}, \mathrm{mmol}(+) / 100 \mathrm{~g}$ \\
\hline 1 & Co & 52 & 27 & 2.5 & 7.6 & 0.5 & 35.0 \\
2 & AS & 7 & 3 & 1.8 & 7.5 & 0.4 & 10.9 \\
3 & MCS & 67 & 37 & 2.7 & 7.3 & 0.2 & 44.8 \\
4 & Co & 55 & 29 & 2.7 & 7.5 & 0.7 & 31.2 \\
5 & Co & 53 & 27 & 2.5 & 7.5 & 1.0 & 35.7 \\
6 & MCS & 55 & 30 & 2.4 & 7.7 & 0.8 & 32.4 \\
7 & Co & 51 & 27 & 2.4 & 7.6 & 0.7 & 31.3 \\
8 & MCS & 60 & 32 & 2.9 & 7.4 & 0.4 & 47.6 \\
9 & Co & 52 & 30 & 2.4 & 7.6 & 0.6 & 31.4 \\
10 & Co & 53 & 28 & 2.7 & 7.6 & 0.5 & 36.0 \\
\hline
\end{tabular}

Subcritical water extraction of BaP from soil samples was conducted in a specially developed extraction cartridge made of stainless steel and equipped with screw-on caps at both ends. It was also equipped with a manometer that included a valve for pressure release to maintain an internal pressure of 55-60 atm. The extraction cartridge containing a sample and water was placed into an oven connected to a temperature regulator.

The process of $\mathrm{BaP}$ analyses in soils based on subcritical water extraction consisted of the following step-by-step operations. An air-dried sample of the soil was ground in a porcelain mortar and passed through a 1 $\mathrm{mm}$ sieve. One gram of sample was placed into the extraction cartridge and $8 \mathrm{~mL}$ of double-distilled water was added. The extraction cartridge was sealed from both sides with the screw caps.

Subsequent extractions were conducted under optimum conditions ( $30 \mathrm{~min}$ at $250^{\circ} \mathrm{C}$ and $100 \mathrm{~atm}$ ) (Sushkova et al., 2014). After cooling, the content of the cartridge was filtered (Whatman no. 1) into a conical glass flask and washed with $2 \mathrm{~mL}$ of double-distilled water. This operation was repeated two or three times, until the filtrate was clear. The aqueous extract was reextracted three times with $5 \mathrm{~mL}$ of $n$-hexane by shaking for $15 \mathrm{~min}$ in a separatory funnel. The hexane extracts were combined and filtered through anhydrous $\mathrm{Na}_{2} \mathrm{SO}_{4}$ and evaporated to dryness in a pear-shaped flask on a vacuum evaporator in a $40^{\circ} \mathrm{C}$ water bath. The residue was dissolved in $1 \mathrm{~mL}$ of acetonitrile by shaking for $30 \mathrm{~min}$.

The efficiency of $\mathrm{BaP}$ extraction from soil was determined using a matrix spike (Certificate 27-08, 2008). The air-dried vegetation sample (1 g) was placed into a round-bottom flask and $\mathrm{BaP}$ standard solution in acetonitrile was added to give $\mathrm{BaP}$ concentrations of 2 , $4,6,8,16$ or $32 \mathrm{ng} \mathrm{g}^{-1}$. After evaporating the solvent for
30 min under a hood under ambient conditions, the BaPspiked soil samples were incubated for $24 \mathrm{~h}$ at $7^{\circ} \mathrm{C}$. The samples were then analyzed by the subcritical extraction method described above.

$\mathrm{BaP}$ in the extracts was quantified by HPLC (Agilent 1260, Germany) with fluorescence (FL-3000) detection following ISO 13877 requirements (ISO 13877-2005, 2005). The BaP peak on chromatograms of soil sample extracts was identified by comparing retention time to that of the analytical standard sample. The limit of BaP detection and quantification were determined using standard solutions and calibration curves. A calibration standard was inserted after every six samples to correct for drift in retention time within a run.

The content of $\mathrm{BaP}$ in the test samples was determined by the external standard method (Certificate 27-08, 2008). The content of $\mathrm{BaP}$ in the soil was calculated from the equation:

$$
C_{s}=k S_{i} \times C_{s t} \times V /\left(S_{s t} \times m\right)
$$

where, $\mathrm{C}_{\mathrm{s}}$ is the content of $\mathrm{BaP}$ in the soil sample $(\mu \mathrm{g} / \mathrm{kg}) ; \mathrm{S}_{\mathrm{st}}$ and $\mathrm{S}_{\mathrm{i}}$ are the $\mathrm{BaP}$ peak areas for the standard solution and the sample, respectively; $\mathrm{C}_{\mathrm{st}}$ is the concentration of the standard $\mathrm{BaP}$ solution $(\mu \mathrm{g} / \mathrm{kg})$; $\mathrm{k}$ is the recovery factor of $\mathrm{BaP}$ from the sample; $\mathrm{V}$ is the volume of the acetonitrile extract $(\mathrm{mL})$; and $\mathrm{m}$ is the mass of the sample $(\mathrm{g})$.

From the results of determining $\mathrm{BaP}$ concentrations in the upper and lower soil layers $\left(\mathrm{C}_{0-5}\right.$ and $\mathrm{C}_{5-20}, \mu \mathrm{g} / \mathrm{kg}$, respectively), the weighted average concentrations of $\mathrm{BaP}$ in the 0 - to $20 \mathrm{~cm}$ layer $\left(\mathrm{C}_{0-20}, \mu \mathrm{g} / \mathrm{kg}\right)$ were calculated from the equation:

$C_{0-20}=\left(5 C_{0-5}+15 C_{5-20}\right) / 20$ 
The vertical distribution coefficients of $\mathrm{BaP}$ between the upper and lower layers $(\mathrm{Kd})$ were calculated from the equation:

$$
K d=15 * C_{5-20} / 5 * C_{0-5}
$$

The averaged $\mathrm{BaP}$ distribution coefficients between the soil layers were also determined for each monitoring plot. The obtained results were processed by mathematical statistics methods using Microsoft EXEL software. Soil properties were analyzed using Russian standard methods (Sokolov, 1975) (Table 1). Soil organic carbon was measured using $0.4 \mathrm{~N}$ potassium bichromate (the Tyurin method modified by Simakov). Soil particle size distribution (silt and clay content) was determined by the pipette method after the pyrophosphate treatment. Cation Exchange Capacity (CEC) of the soil was determined using $1 \mathrm{M}$ ammonium chloride (the Bobko-Askinazi method). The exchangeable potassium was determined by the Machigin (molybdenum blue) method. Adsorbed $\mathrm{Na}$ was analyzed by flame atomic adsorption spectrophotometery. Soil $\mathrm{pH}$ was measured with a $\mathrm{pH}$ electrode using a 1:5 suspension of a soil to water ratio. Exchangeable calcium and magnesium were measured by the titration at $\mathrm{pH} 12.5-13$ and 10 respectively. Carbonates were measured by the Kudrin method using $0.005 \mathrm{NH}_{2} \mathrm{SO}_{4}$ and then an excess of the acid was titrated with alkali.

\section{Results}

\section{Dynamics of Solid Emission Products and the Composition of Pollutants}

The total volume of emissions from the TPPN reached 139 thousand tons. Due to the re-equipment of the TPPN, which started in 2000, the proportion of gas in the fuel exceeded $40 \%$ in 2004 . This resulted in a reduction of solid emissions into the atmosphere down to 54 thousand tons, i.e., more than twice (Fig. 3). In the following two years, the annual volume of solid emissions increased and remained within the range of 83-101 thousand tons during the next five years (up to 2011) (Ecological Messenger of Don, 2013).

From TPPN between 1999 and 2012 (Ecological Messenger of Don, 2013).

The emissions from the TPPN mainly consist of processed coal ash. The coals using on TPPN are enriched with a wide range of organic and inorganic toxic substances (Mandzhieva et al., 2014). The main components of the TPPN emissions are ash, sulfur monoxide, nitrogen oxides, soot (more than $30 \mathrm{t} /$ year), vanadium pentoxide (about $8 \mathrm{t} /$ year), iron oxide (more than $5 \mathrm{t}$ /year), chromic anhydride (about $0.1 \mathrm{t} /$ year), hydrogen fluoride ( $7 \mathrm{~kg} /$ year), etc. Ash retains up to $85 \%$ of the chemical elements that were present in the original coal (Gorobtsova et al., 2005; GOST 14.4.3.06-86, 1986; Hybholt et al., 2011; Gennadiev et al., 2004). It was calculated that PAHs make up about $10 \%$ of the total annual emission from the TPPN (about 90 thousand tons) (Antizar-Ladislao et al., 2006). Some authors indicate that ash can contain up to $60 \%$ PAHs (Gennadiev et al., 2004 ) and $\mathrm{BaP}$ composes up to $10 \%$ of them.

Dynamics of the Content and Distribution of BaP in Soils of the Affected Zone of the TPPN

It was found that the concentration of BAP in soils of the affected zone of the TPPN varied in a wide range: From $8,1 \pm 0,5$ to $275,6 \pm 9,2 \mu \mathrm{g} \mathrm{kg}-1$ in the 0 - to $5 \mathrm{~cm}$ layer and from $7,5 \pm 0,6$ to $117,8 \pm 7,6 \mu \mathrm{g} \mathrm{kg}^{-1}$ in the 5 to $20 \mathrm{~cm}$ layer (i.e., in the ranges of $0.4-13.8$ and $0.4-5.9$ Maximum Permitted Concentration (MPC), respectively) (Table 3). MPC of BAP in soil is $20 \mathrm{ng} \mathrm{g}^{-1}$ (Hygienic Standards HS 2.1.7.2041-06, 2006).

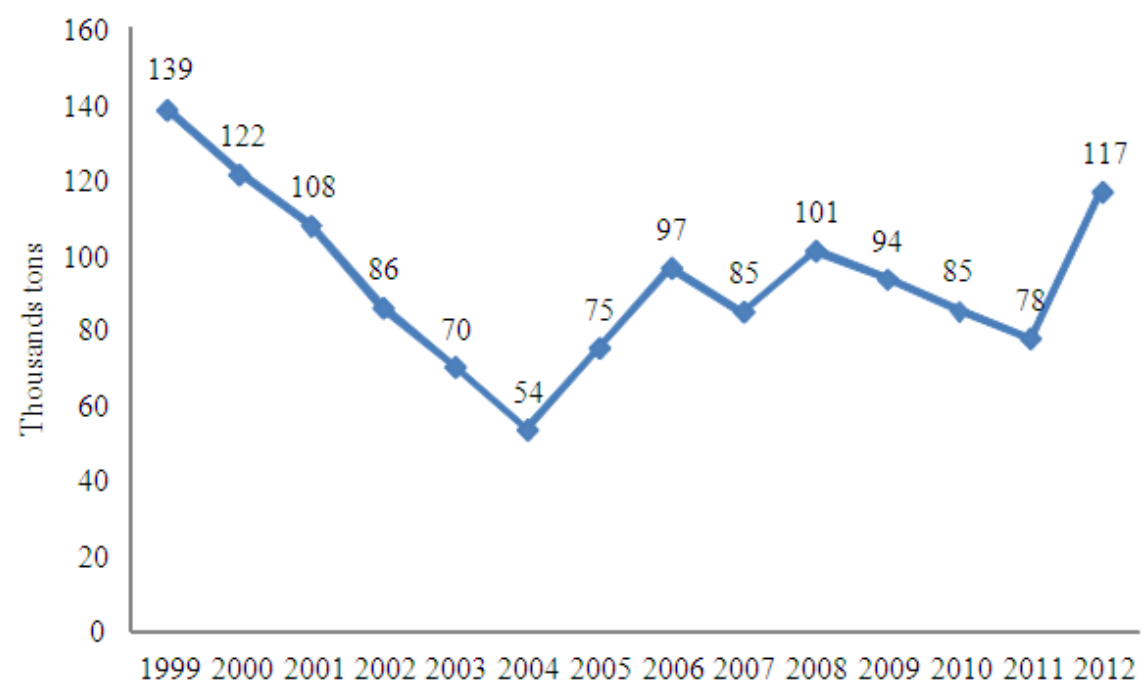

Fig. 3. Dynamics of average pollutant emissions value 
Table 3. The BaP content in soils of monitoring plots for $2008-2012$ years, $\mu \mathrm{g} / \mathrm{kg}$

\begin{tabular}{lllllll}
\hline $\begin{array}{l}\text { Number of monitoring plots, } \\
\text { code and soil types }\end{array}$ & Selection depth, sm & 2008 & 2009 & 2010 & 2011 & 2012 \\
\hline 1. 1ne. Co & $0-5$ & $62.7 \pm 3.4$ & $72.3 \pm 1.7$ & $54.9 \pm 1.4$ & $24.0 \pm 0.9$ & $48.9 \pm 2.5$ \\
& $5-20$ & $24.8 \pm 1.1$ & $23.9 \pm 1.7$ & $26.6 \pm 0.9$ & $17.1 \pm 2.1$ & $22.0 \pm 1.8$ \\
2. 3sw. AS & $0-5$ & $28.0 \pm 1.3$ & $18.2 \pm 1.4$ & $18.4 \pm 1.6$ & $22.7 \pm 0.1$ & $34.7 \pm 3.2$ \\
& $5-20$ & $27.3 \pm 2.1$ & $26.3 \pm 2.1$ & $24.7 \pm 2.4$ & $19.4 \pm 1.8$ & $37.3 \pm 1.7$ \\
3. 2.7sw. MCS & $0-5$ & $69.5 \pm 3.3$ & $123.9 \pm 6.7$ & $57.3 \pm 4.7$ & $24.5 \pm 2.7$ & $34.0 \pm 2.4$ \\
& $5-20$ & $18.4 \pm 0.6$ & $62.8 \pm 5.4$ & $19.8 \pm 1.5$ & $8.6 \pm 1.2$ & $17.5 \pm 0.8$ \\
4. 1.6nw. Co & $0-5$ & $182.5 \pm 3.5$ & $275.6 \pm 9.2$ & $84.2 \pm 6.8$ & $62.4 \pm 5.8$ & $95.3 \pm 12.7$ \\
& $5-20$ & $113.9 \pm 16.4$ & $117.8 \pm 7.6$ & $47.8 \pm 3.8$ & $37.1 \pm 2.6$ & $62.2 \pm 4.5$ \\
5. 1.2nw. Co & $0-5$ & $118.5 \pm 4.0$ & $138.1 \pm 8.6$ & $65.4 \pm 3.4$ & $45.4 \pm 4.3$ & $113.4 \pm 11.6$ \\
& $5-20$ & $72.8 \pm 8.2$ & $92.1 \pm 3.7$ & $45.3 \pm 2.0$ & $35.9 \pm 2.8$ & $69.8 \pm 5.6$ \\
6. 2n. MCS & $0-5$ & $46.6 \pm 2.8$ & $67.4 \pm 2.8$ & $32.4 \pm 1.4$ & $34.3 \pm 2.6$ & $75.4 \pm 5.8$ \\
& $5-20$ & $25.7 \pm 1.5$ & $36.7 \pm 2.2$ & $16.2 \pm 1.5$ & $8.1 \pm 0.5$ & $36.0 \pm 2.9$ \\
7. 1.5n. Co & $0-5$ & $38.5 \pm 2.1$ & $87.6 \pm 3.7$ & $39.5 \pm 2.4$ & $36.4 \pm 2.3$ & $36.0 \pm 1.3$ \\
& $5-20$ & $17.3 \pm 1.7$ & $35.9 \pm 2.1$ & $14.4 \pm 1.5$ & $16.3 \pm 0.4$ & $24.7 \pm 1.4$ \\
8. 5nw. MCS & $0-5$ & $60.3 \pm 3.4$ & $82.4 \pm 3.6$ & $47.8 \pm 3.0$ & $35.9 \pm 1.6$ & $39.3 \pm 2.4$ \\
& $5-20$ & $41.7 \pm 1.7$ & $28.4 \pm 1.7$ & $28.6 \pm 2.7$ & $24.6 \pm 2.1$ & $17.4 \pm 0.8$ \\
9. 15nw. Co & $0-5$ & $27.4 \pm 0.9$ & $25.6 \pm 2.6$ & $18.4 \pm 1.2$ & $13.0 \pm 0.7$ & $39.8 \pm 2.1$ \\
& $5-20$ & $11.8 \pm 0.3$ & $18.4 \pm 0.7$ & $11.9 \pm 0.7$ & $11.9 \pm 0.4$ & $27.3 \pm 1.5$ \\
10. 20nw. Co & $0-5$ & $26.9 \pm 1.5$ & $48.0 \pm 4.2$ & $28.6 \pm 2.2$ & $12.1 \pm 0.8$ & $68.2 \pm 3.6$ \\
& $5-20$ & $17.4 \pm 0.7$ & $32.5 \pm 3.2$ & $14.1 \pm 0.7$ & $7.5 \pm 0.6$ & $29.1 \pm 1.4$ \\
\hline
\end{tabular}

On most of the plots, the concentrations of $\mathrm{BaP}$ in the both soil layers varied synchronously (Table 3).

The weighted average $\mathrm{BaP}$ concentrations in the 0 to $20 \mathrm{~cm}$ layer of soils on the monitoring plots during the period from 2008 to 2012 are shown in Fig. 4 and 5. The results for the soils located along the predominant wind direction (to the northwest) and within a radius of $1-3 \mathrm{~km}$ from the plant in the northern, northeastern and southwestern directions are shown separately (Fig. 4 and 5 respectively).

\section{Discussion}

The analysis of the results shows that the accumulation of $\mathrm{BaP}$ in the soils of the studied area depends on the distance of the controlled plots from the emission source and their location with respect to it. The major part of pollutants accumulates in the soils of the northwestern direction from the TPPN (Fig. 4). The most significant pollution of soils in this direction is observed within a radius of $5 \mathrm{~km}$, with a maximum at $1.6 \mathrm{~km}$, where $\mathrm{C}_{0-20}$ reached 56,9-157,25 $\mathrm{\mu g} \mathrm{kg}^{-1}$ (2.8-7.9 MPC) and $\mathrm{C}_{0-5}$ reached $275,6 \pm 9,2 \mu \mathrm{g} \mathrm{kg}$ (13.8 MPC) in 2009 (Table 3 ). When the distance from the emission source increases, the level of contamination with BaP gradually decreases to a minimum at $15 \mathrm{~km}$ from the plant, where $\mathrm{C}_{0-20}$ varies in the range of 0.6-1.5 MPC and $\mathrm{C}_{0-5}$ does not exceed 2 MPC.

In all the soils located along the predominant wind direction, there were observed the stable $\mathrm{BaP}$ contamination with MPC increasing in $20 \mathrm{~cm}$ layer of monitoring plots at distances from $1.2 \mathrm{nw}$ to $20 \mathrm{nw}$. The decrease of $\mathrm{BaP}$ content in the entire 0 - to $20 \mathrm{~cm}$ layer was observed from 2008 to 2011 years of observations and increase of $\mathrm{BaP}$ content in 2012. This tendency is most manifested in the soil of plot 4 with the maximum level of contamination (Fig. 4), where the concentration of BaP decreased in 4 times: From 157.3 to $56.9 \mu \mathrm{g} \mathrm{kg}^{-1}$. An almost similar decrease of $\mathrm{C}_{0-20}$ (from 103.6-46.4 to 38.3-22.9 $\mu \mathrm{g} \mathrm{kg}^{-1}$, i.e., by 2.7-2 times) was observed on plots 1.2 and 5nw.

In the most remote point of group I (20nw), as well as in almost all soils of group II (Fig. 5), the content of $\mathrm{BaP}$ remained low (at 0.6-4 MPC) but in most cases it remains above the MPC. In points $20 \mathrm{nw}$ and 1 ne, a tendency of slow decrease in the concentration of $\mathrm{BaP}$ (by about 2 times for 6 years) was observed; on the other plots, the most significant decrease in $\mathrm{BaP}$ concentration was observed only in the years from 2009 to 2011.

The revealed tendencies in the decrease of $\mathrm{BaP}$ concentration in the soils of monitoring plots are analogous to those observed for the decrease in the volume of solid emissions from the plant during the period from 2004 to 2011 (Fig. 3). In most of the curves, the peaks of increasing and decreasing $\mathrm{BaP}$ concentration coincide with each others and with the peaks of soot emission but are delayed from the emission dynamics by about a year. After 2004, the decrease of $\mathrm{BaP}$ concentration in the soil continued, in spite of the relative stabilization of emissions from the TPPN and accelerated during the period of the last decrease in the volume of solid emissions beginning from 2008.

The concentrations of $\mathrm{BaP}$ in the 0 - to 5- and 5- to $20 \mathrm{~cm}$ layers of soils on the monitoring plots averaged for the period of 2008-2012, when the annual emissions from the power plant were stabilized at a 
level of 75-101 thousand tons. In all the sampling points on chernozemic and meadow-chernozemic soils, the averaged concentrations of $\mathrm{BaP}$ in the upper soil layer exceed its contents in the lower layer by
1.5-2 times (Table 3). An exception is point 2 on sandy alluvial soil located in the Tuzlov River floodplain, where the concentrations of $\mathrm{BaP}$ in the both layers are similar and do not exceed the MPC.

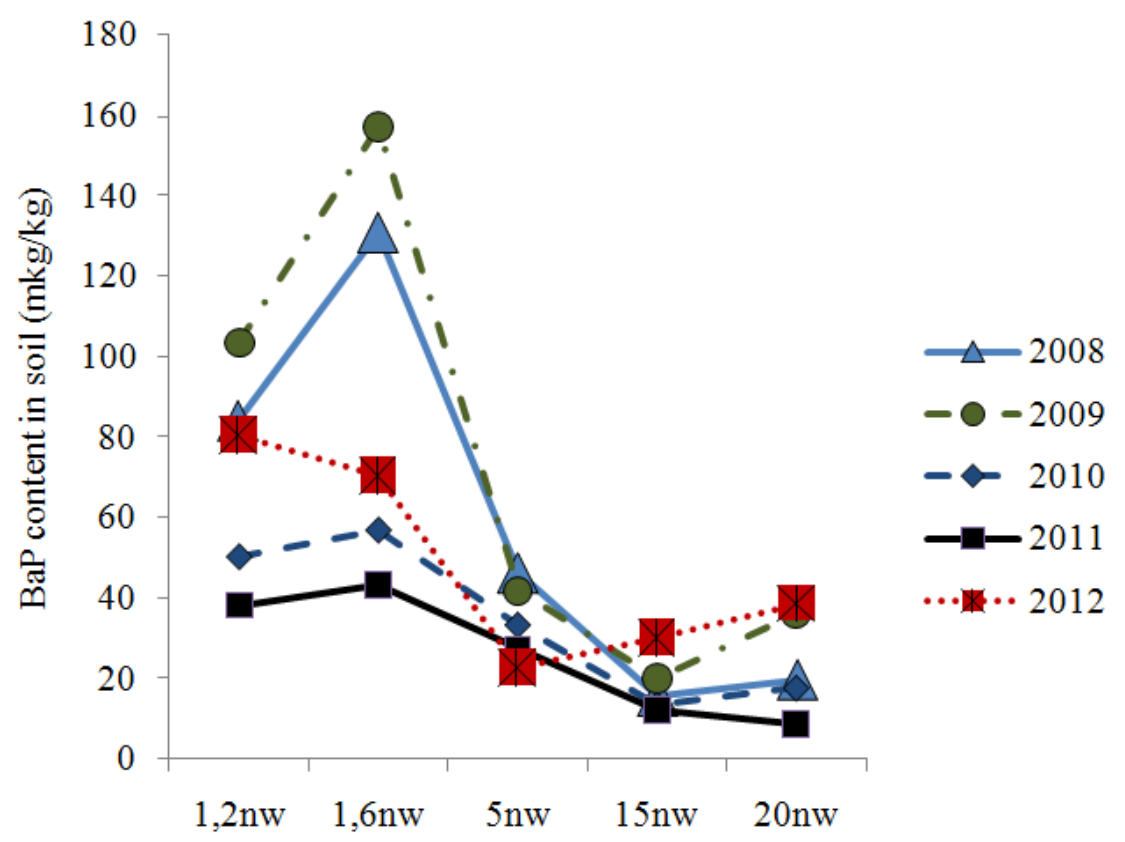

Distance and direction of monitoring plots from NRPP

Fig. 4. Dynamics of BaP average concentrations in $20 \mathrm{~cm}$ layer of soil monitoring plots in NRPP emission zone on the north-westthrough the prevailing direction of the wind rose. The line indicates the level of MPC in the soil

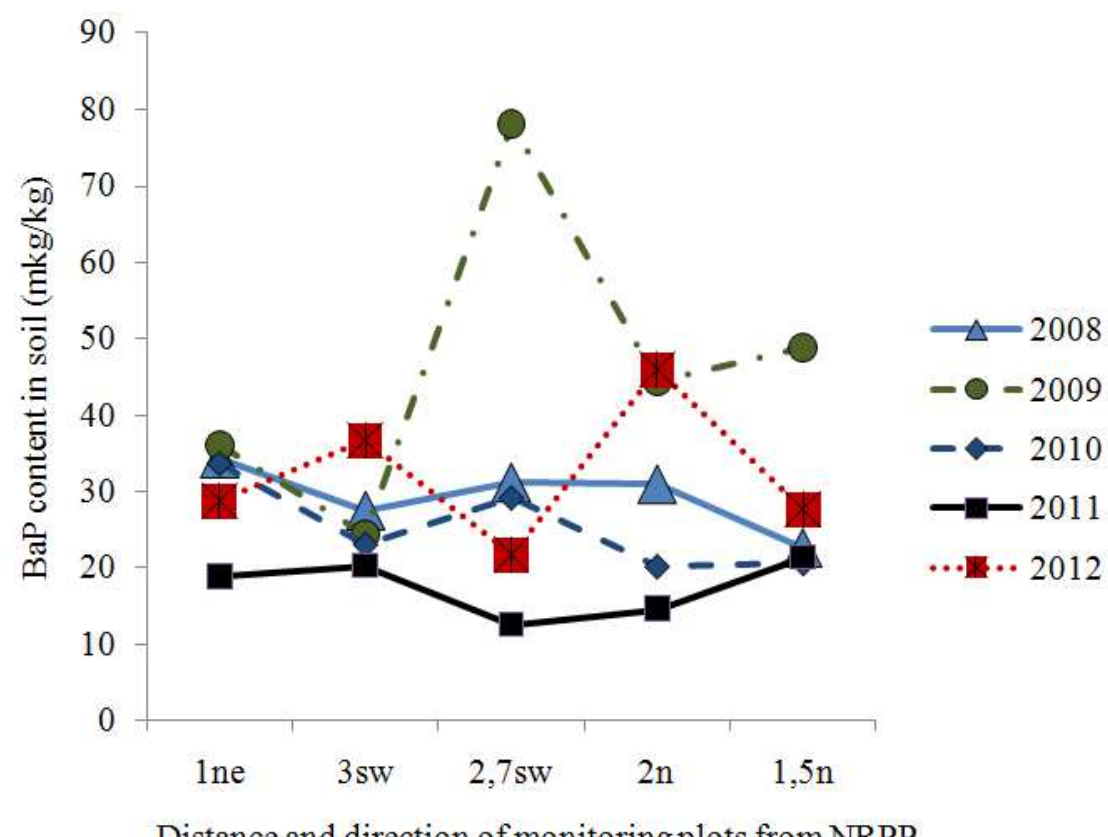

Fig. 5. Dynamics of BaP average concentrations in $20 \mathrm{~cm}$ layer of soil monitoring plots in NRPP emission zone around NRPP on north/northeast and southwest directions. The line indicates the level of MPC in the soil 
Our studies showed that, the content of $\mathrm{BaP}$ in the both layers remained above the MPC during the entire period of observations. However, in 2011, the concentration of $\mathrm{BaP}$ in the soils of most plots decreased to the MPC level; only along the predominant wind direction (within the radius of $5 \mathrm{~km}$ ), it still exceeded this level by 1.2-2 times.

The intensive decrease in the content of $\mathrm{BaP}$ in the soil of monitoring plot $5 \mathrm{nw}$ compared to plot 1,6nw (by more than 3.5 times) indicates that the distribution area of the densest plume containing the maximum amount of pollutant is about $5 \mathrm{~km}$ to the northwest and the maximum fallouts are observed at a distance of about 1.6 $\mathrm{km}$ (Sushkova et al., 2012). The areas located around the TPPN up to $3 \mathrm{~km}$ in the northern/northeastern and southwestern directions are less contaminated. An exception is the soil on plot $.7 \mathrm{sw}$, which is the closest to group I, where the concentrations of $\mathrm{BaP}$ in the 0 - to 20 cm layer reached $12.8-78 \mu \mathrm{g} \mathrm{kg}^{-1}$ in 2008- 2012 .

It should be noted that the soils of the plots located at 1-2 km to the north and northeast of the plant are almost not subjected to the impact of polluting emissions. During the entire period of observations, the content of $\mathrm{BaP}$ in the 0 - to $20 \mathrm{~cm}$ layer of soils on these plots located at a short distance from the plant $(1-2 \mathrm{~km})$ exceeded the MPC by no more than 2.5 times except only monitoring plot $27 \mathrm{sw}$ in 2009 (Fig. 5).

The soils on the most remote monitoring plot 10 (20nw) occupy a special place in the description of the affected zone of TPPN. The obtained data indicate the presence of additional sources of pollutant emission near the plot: Exhausts from motor vehicles on the M-4 Don highway, which passes at $350 \mathrm{~m}$ from the sampling site. The plot is located within the V-shaped area enclosed by two highways (the Rostov-Moscow road from the northwest and the Rostov-Novocherkassk road from the southeast), which results in the contamination of soils with vehicle exhausts containing $\mathrm{BaP}$. In addition, this plot is apparently subjected to the plumes from the Novocherkassk dumps, as well as combustion products formed at the stove heating of houses in the village of Grushevskaya. Nonetheless, the accumulation of the pollutant in the soil due to the additional emission sources is significantly lower than that caused by the TPPN.

The period of half-decrease (T50) of the pollutant concentration in the most contaminated soils varies in the range of 1-5 years; during the period of 2009-2011, the process was accelerated and T50 decreased to 0.1-1 years. On the slightly contaminated soils, T50 did not exceed 6 years or could not be determined at all (Oros et al., 2007).

The almost simultaneous decrease of $\mathrm{BaP}$ concentrations in the upper and lower layers of soil, as well as the acceleration of this process to 2011, indicates the leading role of the microbial degradation of the pollutant in the entire soil layer under study. Although the photo-oxidation of $\mathrm{BaP}$ on the soil surface also cannot be excluded (Shabad, 1982), its contribution to the decomposition is apparently minimum because of the shielding of molecules sorbed by soil and soot particles.

It is known that $\mathrm{BaP}$ belongs to the persistent pollutants, because microorganisms are incapable of using 4-5-ring PAHs as the only source of carbon and energy. Nonetheless, the microbial degradation of $\mathrm{BaP}$ occurs in oxidative conditions under the effect of microorganisms utilizing 2-3-ring PAHs, which usually accumulate in the contaminated soils because of the adaptation of soil microflora (Shabad, 1982; Endovitsky et al., 2014). The accelerated degradation of $\mathrm{BaP}$, which is observed in the most contaminated soils, is due to the faster adaptation of microorganisms in the presence of the selective factor (Gabov et al., 2007; Galiulin and Bashkin, 1999). The slower decrease of $\mathrm{BaP}$ concentration in the slightly contaminated soils can be related to their low availability to biodestructors due to the strong sorption by soil humus or pyrogenic particles (Augusto et al., 2013; Batukaev et al., 2014). However, the absence of appreciable BaP accumulation in the soil, in spite of the continuing input of soot fallouts in the affected zone of the TPPN, can also argue for the degradation of the pollutant.

The analysis of the physicochemical and agrochemical properties of soils in the studied areas (Table 2) suggests that, in spite of the intensive longterm technogenic load and the high contents of BaP and heavy metals in soils of the studied areas, the high level of fertility still remains in the affected zone of the TPPN, which sustains the ecological balance and forms the basis for the stability and balanced functioning of the ecosystem (Nazarenko et al., 2007; Page et al., 2006; Sushkova et al., 2014).

The comparison of the concentrations of $\mathrm{BaP}$ in the 0 - to 5- and 5- to $20 \mathrm{~cm}$ layers showed that the surface accumulation of $\mathrm{BaP}$ prevails in the chernozemic soils of heavy texture occurring in the affected zone of the TPPN. However, the relatively high $\mathrm{Kd}$ of the pollutant between these layers, which exceed 1 in most cases and reach 2.6, indicate the migration of $\mathrm{BaP}$ throughout the soil profile, at least within the $0-$ to $20 \mathrm{~cm}$ layer. The most intense migration of $\mathrm{BaP}$ proceeds in the floodplain soil of the Tuzla River floodplain, where the value of $\mathrm{Kd}$ reaches 4.3 (Table 4 ).

The low mobility of $\mathrm{BaP}$ in the zonal chernozemic soils is due to its low solubility in water, high lipophilicity and high capacity of being sorbed by soil organic matter, whose content is maximum in the fine fraction of soil and depends on the content of fine particles. In the less humified soil of light texture, the migration of $\mathrm{BaP}$ is appreciably lower.

The obtained data agree with the results of studies (Sushkova et al., 2014; Gabov et al., 2007; Minkina et al., 2011; Nazarenko et al., 2007), which indicate the effect of soil texture on the migration of $\mathrm{BaP}$ in the soils of natural and technogenic landscapes. 
Table 4. Kd in the 0 - to 5- and 5- to $20 \mathrm{~cm}$ layers in soils of monitoring plots for 2008-2012 years

\begin{tabular}{lllllll}
\hline Number of monitoring plots, code and soil types & 2008 & 2009 & 2010 & 2011 & 2012 & 2013 \\
\hline 1. 1ne. Co & 1.2 & 1.0 & 1.5 & 2.1 & 1.3 & 1.3 \\
2. 3sw. AS & 2.9 & 4.3 & 4.0 & 2.6 & 3.2 & 1.6 \\
3. 2.7sw. MCS & 0.8 & 1.5 & 1.0 & 1.1 & 1.5 & 1.5 \\
4. 1.6nw. Co & 1.9 & 1.3 & 1.7 & 1.8 & 2.0 & 1.5 \\
5. 1.2nw. Co & 1.8 & 2.0 & 2.1 & 2.4 & 1.8 & 1.8 \\
6. 2n. MCS & 1.7 & 1.6 & 1.5 & 0.7 & 1.4 & 0.7 \\
7. 1.5 n. Co & 1.3 & 1.2 & 1.1 & 1.3 & 2.1 & 1.2 \\
8. 5nw. MCS & 2.1 & 1.0 & 1.8 & 2.1 & 1.3 & 1.1 \\
9.15nw. Co & 1.3 & 2.2 & 1.9 & 2.7 & 2.1 & 2.2 \\
10.20nw. Co & 1.9 & 2.0 & 1.5 & 1.9 & 1.3 & 2.6 \\
\hline
\end{tabular}

\section{Conclusion}

The tendencies in the distribution and accumulation of $\mathrm{BaP}$ in the studied soils coincided during the 6 years of monitoring studies. The toxic emissions from the TPPN are the main factor of technogenic impact on the soils in the region under study; vehicle exhausts can be sources of additional BaP emission. A gradual decrease of the pollutant content in the soils of the studied areas was revealed during the period from 2008 to 2011, which was related to the significant decrease in the volume of pollutant emissions from the plant and the self-purification capacity of soils due to the microbiological and other mechanisms of $\mathrm{BaP}$ degradation. After this period in 2012 the increase of $\mathrm{BaP}$ content in soils were observed according the increase of total emission value of TPPN. In spite of the conservation measures undertaken at the power plant, the atmospheric emissions from the TPPN have still the predominant effect on the environmental situation in the adjacent areas at present.

The particle size distribution in the soils significantly affects the accumulation and differentiation of $\mathrm{BaP}$ in the soil profile. The elevated values of $\mathrm{Kd}$ in the sandy floodplain soil of the Tuzlov River floodplain indicate the possible migration of the hazardous pollutant to the ground and surface waters of the studied region.

\section{Funding Information}

This research was supported by projects of the Ministry of Education and Science of Russia, no. $5.885 .2014 / \mathrm{K}$ and Grant of President of Russian Federation no. MK-6827.2015.4, RFBR no. 15-3521134. Analytical work was carried out on the equipment of Centers for collective use of Southern Federal University "High Technology" grant RFMEFI59414X0002, "Biotechnology, Biomedical and Environmental Monitoring".

\section{Author's Contributions}

Svetlana Sushkova: Participated in all experiments, coordinated the data-analysis, contributed to the writing of the manuscript, designed the research plan and organized the study.

Tatiana Minkina: Designed the research plan and organized the study.

Abdulmalik Batukaev: Designed the research plan and organized the study and coordinated the mouse work.

Irina Turina: Participated in all experiments, coordinated the data-analysis and contributed to the writing of the manuscript and coordinated the mouse work.

Saglara Mandzhieva: Participated in all experiments, coordinated the data-analysis and contributed to the writing of the manuscript.

Galina Vasilyeva: Designed the research plan and organized the study and coordinated the mouse work.

Rıdvan Kızılkaya: Designed the research plan and organized the study.

Inna Zamulina: Participated in all experiments, coordinated the data-analysis, contributed to the writing of the manuscript and coordinated the mouse work.

Izzet Akca: Designed the research plan, organized the study and coordinated the mouse work.

\section{Ethics}

Svetlana Sushkova, Tatiana Minkina, Abdulmalik Batukaev, Irina Turina, Saglara Mandzhieva, Galina Vasilyeva, Rıdvan Kızılkaya, Inna Zamulina and Izzet Akca state that there are no conflicts of interest.

\section{References}

Sokolov, A., 1975. Agrochemical methods of soil study. Science Publishing, Moscow.

Antizar-Ladislao, B., J. Lopez-Real and A. Beck, 2006. Degradation of Polycyclic Aromatic Hydrocarbons (PAHs) in an aged coal tar contaminated soil under in-vessel composting conditions. Environ. Pollut., 141: 459-468. DOI: 10.1016/j.envpol.2005.08.066

Augusto, S., M.J. Pereira, C. Máguas and C. Branquinho, 2013. A step towards the use of biomonitors as estimators of atmospheric PAHs for regulatory purposes. Chemosphere, 92: 626-632. DOI: 10.1016/j.chemosphere.2013.03.068 
Batukaev, A.A., A.P. Endovitsky, T.M. Minkina, V.P. Kalinichenko and Z.S. Dikaev et al., 2014. Chemical equilibrium of soil solution in steppe zone soil. Am. J. Agric. Biol. Sci., 9: 420-429.

DOI: 10.3844/ajabssp.2014.420.429

Callén, M.S., J.M. López, A. Iturmendi and A.M. Mastral, 2013. Nature and sources of particle associated Polycyclic Aromatic Hydrocarbons (PAH) in the atmospheric environment of an urban area. Environ. Pollut., 183: 166-174.

DOI: 10.1016/j.envpol.2012.11.009

Anonymous, 2002. Contaminants in Soil: Collation of Toxicological Data and intake Values for Humans. 1st Edn., Department for Environment, Food and Rural Affairs and the Environment Agency, ISBN-10: 1857057414, pp: 20.

Directive Document 52.10.556-95, 2002. Methodical Instructions. Definition of Polluting Substances in Sediments and Suspension. Roshydromet, Moscow.

Ecological Messenger of Don, 2013. About environmental conditions and natural resources of the Rostov Region in 2012. Rostov-on-Don, Administration of Rostov Region, The Committee on Environment and Natural Resources.

Endovitsky, A.P., T.M. Minkina, V.P. Kalinichenko, A.A. Batukaev and Z.S. Dikaev et al., 2014. The association of ions in the soil solution of saline soils. Am. J. Agric. Biol. Sci., 9: 238-244. DOI: 10.3844/ajabssp.2014.238.244

Gabov, D.N., V.A. Beznosikov and B.M. Kondratenok, 2007. Polycyclic aromatic hydrocarbons in background podzolic and gleyic peat-podzolic soils. Eurasian Soil Sci., 40: 282-291. DOI: $10.1134 / \mathrm{S} 1064229307030039$

Galiulin, R. and V. Bashkin, 1999. Behavior of persistent organic pollutants in the atmospheric fallout-plant system. Agrokhimiya, 12: 69-77.

Gennadiev, A.N., Y.I. Pikovskii, S. Chernyanskii, T.A. Alekseeva and R.G. Kovach, 2004. Forms of polycyclic aromatic hydrocarbons and factors of their accumulations in soils affected by technogenic pollution (Moscow oblast). Eurasian Soil Sci., 37: 697-709.

Gorobtsova , O.N., O.N. Nazarenko, T.M. Minkina, N.I. Borisenko and A.V. Yaroshchuk, 2005. Role of soil cover in the accumulation and migration of polycyclic aromatic hydrocarbons under technogenic contamination. Izvestiya Vuzov Severo Kaucasus Region Estestvennye Nauki, 1: 73-79.

GOST 14.4.3.06-86, 1986. Nature protection. Soils. General requirements for the classification of soils in accordance with the impact of chemical pollutants on them. State Standards Publishing House, Moscow.
GOST 17.4.1.02.-83, 2004. State standard (Russian Federation State standard specification) conservation. Soils. Classification of Chemicals for Pollution Control, State Standards Publishing House, Moscow.

GOST 17.4.3.01-83, 2004. Nature protection. Soils. The general requirements to sampling, State Standards Publishing House, Moscow.

GOST 17.4.4.02-84, 1986. Nature protection. Soils. Methods of selection and preparation of tests for the chemical, bacteriological, gelmintological analysis, State Standards Publishing House, Moscow.

GOST 26423-85, 1985. Soils. Methods for determination of specific electric conductivity, $\mathrm{pH}$ and dissolved solids, State Standards Publishing House, Moscow.

Hybholt, T.K., J. Aamand and A. Johnsen, 2011. Quantification of centimeter-scale spatial variation in PAH, glucose and benzoic acid mineralization and soil organic matter in road-side soil. Environ. Pollut., 159: 1085-1091.

DOI: $10.1016 /$ j.envpol.2011.02.028

Hygienic Standards HS 2.1.7.2041-06, 2006. Maximum Permissible Concentration (MPC) of chemicals in the soil, Federal Service for Supervision of Consumer Rights Protection and Human Welfare, Enacted 01.04.2006, 2006.

ISO 13877-2005, 2005. Soil Quality-determination of polynuclear aromatic hydrocarbons-method using high-performance liquid chromatography.

Jian, Y., L. Wang, P.P. Fu and H. Yu, 2004. Photomutagenicity of 16 polycyclic aromatic hydrocarbons from the US EPA priority pollutant list. Mutation Res., 557: 99-108. DOI: 10.1016/j.mrgentox.2003.10.004

Mandzhieva, S.S., T.M. Minkina, S.N. Sushkova, G.V. Motuzova and T. Bauer et al., 2014. The group composition of metal compounds in soil as an index of soil ecological state. Am. J. Agric. Biol. Sci., 9: 19-24. DOI: 10.3844/ajabssp.2014.19.24

Minkina, T.M., D.L. Pinskii, S.S. Mandzhieva, E.M. Antonenko and S.S. Sushkova, 2011. Effect of the particle-size distribution on the adsorption of copper, lead and zinc by Chernozemic soils of Rostov oblast. Eurasian Soil Sci., 44: 1193-1200. DOI: 10.1134/S1064229311110044

Nazarenko, O.G., O.N. Gorobtsova, T.M. Minkina and S.S. Mandzhieva, 2007. Integral contamination index in the environmental assessment of technogenic areas. Proceedings of 3rd International Science Conference on Current Problems of Soil Pollution, (PSP'07), Moscow, pp: 130-133.

Oros, D.R., J.R.M. Ross, R.B. Spies and T. Mumley, 2007. Polycyclic Aromatic Hydrocarbon (PAH) contamination in San Francisco Bay: A 10-year retrospective of monitoring in an urbanized estuary. Environ. Res., 105: 101-118. DOI: $10.1016 /$ j.envres.2006.10.007 
Page, D.S., J.S. Brown, P.D. Boehm, A.E. Bence and J.M. Neff, 2006. A hierarchical approach measures the aerial extent and concentration levels of PAHcontaminated shoreline sediments at historic industrial sites in Prince William Sound, Alaska. Marine Pollut. Bull., 52: 367-379.

DOI: 10.1016/j.marpolbul.2005.08.027

Pereira, T.S., L.S. Beltrami, J.A.V. Rocha, F.P. Broto and L.R. Comellas et al., 2013. Toxicogenetic monitoring in urban cities exposed to different airborne contaminants. Ecotoxicol. Environ. Safety, 90: 174-182. DOI: 10.1016/j.ecoenv.2012.12.029

Certificate 27-08, 2008. Procedure of measurements benz(a)pyrene content in soils, sediments and sludges by highly effective liquid chromatography method, Moscow.

Shabad, L., 1982. Chemical carcinogens in the natural environment. Integrated Global Monitoring of Pollution in the Natural Environment, Gidrometeoizdat, Leningrad.

Singh, D.P., R. Gadi, T.K. Mandal, T. Saud and M. Saxena et al., 2013. Emissions estimates of PAH from biomass fuels used in rural sector of IndoGangetic Plains of India. Atmospheric Environ., 68: 120-126. DOI: 10.1016/j.atmosenv.2012.11.042

Sushkova, S.N., T.M. Minkina, S.S. Mandzhieva, N.I. Borisenko and T.I. Fedchenko, 2012. Determination of 3, 4-benz[a]pyrene in soils adjacent to the Novocherkassk power plant by subcritical water extraction. Plodorodie, 4: 55-56.

Sushkova, S.N., T.M. Minkina, S.S. Mandzhieva and I.G. Tjurina, 2013. Elaboration and approbation of methods for benzo[a]pyrene extraction from soils for monitoring of the ecological state in technogenic landscapes. World Applied Sci. J., 25: 1432-1437. DOI: 10.5829/idosi.wasj.2013.25.10.11237

Sushkova, S.N., G.K. Vasilyeva, T.M. Minkina, S.S. Mandzhieva and I.G. Tjurina et al., 2014. New method for benzo[a]pyrene analysis in plant material using subcritical water extraction. J. Geochem. Exploration, 144: 267-272.
Sushkova, S., T. Minkina, S. Mandzhieva, N. Borisenko and G. Vasilyeva et al., 2015a. Approbation of express-method for benzo[a]pyrene extraction from soils in the technogenic emission zone territories. Eurasian J. Soil Sci., 4: 15-21. DOI: $10.18393 /$ ejss. 48158

Sushkova, S.N., T.M. Minkina, S.S. Mandzhieva, G.K. Vasilyeva and N.I. Borisenko et al., 2015 b. Optimization of conditions for benzo[a]pyrene extraction from soils. J. Soil Sediments.

Tobiszewski, M. and J. Namiesnik, 2012. PAH diagnostic ratios for the identification of pollution emission sources. Environ. Pollut., 162: 110-119.

Wenzl, T., R. Simon, J. Kleiner and E. Anklam, 2006. Analytical methods for Polycyclic Aromatic Hydrocarbons (PAHs) in food and the environment needed for new food legislation in the European Union. Trends Analytical Chem., 25: 716-725.

Witter, A.E., M.H. Nguyen, S. Baidar and P.B. Sak, 2014. Coal-tar-based sealcoated pavement: A major PAH source to urban stream sediments. Environ. Pollut., 185: 59-68. DOI: $10.1016 / \mathrm{j}$. envpol.2013.10.015

Li, X.H., L.L. Ma, X.F. Liu, S. Fu and H.X. Cheng et al., 2006. Polycyclic aromatic hydrocarbon in urban soil from Beijing, China. J. Environ. Sci., 18: 944-950. PMID: 17278752

Yam, R.C.M. and W.H. Leung, 2013. Emissions trading in Hong Kong and the pearl river delta region-a modeling approach to trade decisions in Hong Kong's electricity industry. Environ. Sci. Policy, 31: 1-12. DOI: 10.1016/j.envsci.2013.03.010

Zhu, Y., L. Yang, Q. Yuan, C. Yan and C. Dong et al., 2014. Airborne particulate Polycyclic Aromatic Hydrocarbon (PAH) pollution in a background site in the North China Plain: Concentration, size distribution, toxicity and sources. Sci. Total Environ., 466-467: 357-368.

DOI: $10.1016 /$ j.scitotenv.2013.07.030 